This is an open access article under the CC-BY-SA license (https://creativecommons.org/licenses/by-sa/4.0/) ISSN 2355-6102 (print), ISSN 2502-0404 (online)

\title{
PENGARUH KOMPOS LIMBAH KULIT KOPI (Coffea) TERHADAP PERTUMBUHAN TANAMAN KACANG PANJANG (Vigna sinensis L.)
}

\author{
${ }^{1}$ Hartati, ${ }^{1}$ Nikman Azmin*, ${ }^{1}$ Andang dan ${ }^{2}$ Muhammad Eka Hidayatullah \\ ${ }^{1}$ Sekolah Tinggi Keguruan dan Ilmu Pendidikan (STKIP) Bima \\ Author correspondent: biologinikman@gmail.com
}

\section{Diterima 19 Agustus 2019 disetujui 25 September 2019}

\begin{abstract}
This study aims to determine the effect of coffee skin waste compost on the growth of long beans (Vigna sinensis L.). This study uses a completely randomized design (CRD). Data analysis using ANOVA test. The results of the research showed that the growth of Vigna sinensis L. after being given coffee waste skin compost fertilizer was an average plant height and number of leaves after 2 weeks, 4 weeks and 6 weeks, ie with a dose of treatment A1 (33.00 cm and 19 strands), A2 ( $48.90 \mathrm{~cm}$ and 25 strands), A3 (61.27 cm and 3 strands) and A4 $(61.27 \mathrm{~cm}$ and 3 strands). While the results of the analysis of the value of Fcount and Ftable from the high growth of Vigna sinensis L.. showed at age 2 weeks $8.13>4.07,4$ weeks $7.99>4.07$, and 6 weeks $14.34>4.07$. While the results of the analysis of the value of Fcount and Ftable from most of the leaves of Vigna sinensis L. at the age of 2 weeks $17.00>4.07,4$ weeks 7.58 > 4.07, and 6 weeks 6.44 4.07. The use of coffee skin waste compost fertilizer can increase the high growth and number of leaves of the Vigna sinensis L.. plant.
\end{abstract}

Keywords: Compost, Coffee Skin, Long Beans, Organic Fertilizers

\section{PENDAHULUAN}

Kacang panjang (Vigna sinensis L.) merupakan salah satu jenis tanaman kacang-kacangan yang sering dibudidayakan diseluruh dunia (Qasem dan Biftu, 2010) oleh petani, baik secara monokultur maupun sebagai tanaman sela. Tanaman ini mudah ditanam di lahan seperti dataran rendah maupun dataran tinggi, baik di tanah sawah, tegalan, maupun di tanah pekarangan (Samadi, 2013), tanaman ini juga memiliki kandungan gizi yang tinggi yaitu vitamin A, vitamin $\mathrm{B}$, vitamin $\mathrm{C}$, dan mineral pada polongnya sedangkan bijinya mengandung protein, lemak, dan karbohidrat (Simarmata et al 2015), selain itu tingkat konsumsi masyarakat terhadap tanaman ini cukup tinggi dan merupakan salah satu jenis sayuran yang cukup popular yang sering terlihat di pasar (Fahruddin, 2012) yang menempati urutan ke- 8 dari 20 jenis sayuran yang dikonsumsi di Indonesia
(Yudha et al 2016). Kacang panjang memang tanaman komersial karena hasilnya mudah dipasarkan namun ketersediaan pupuk organik saat ini cukup terbatas (Afrizo, 2015) maka diperlukan pupuk alternatif yang baik, aman dan murah agar produksi semakin tinggi, salah satunya seperti penggunaan limbah kolit kopi sebagai bahan pembuatan pupuk kompos.

Rizkywan, (2014) mengatakan bahwa limbah kulit kopi banyak mengandung protein, vitamin A, lemak dan karbohidrat (Haryanto, 2011). Limbah kulit kopi dapat dijadikan sebagai bahan dasar pembuatn pupuk kompos (Afrizon, 2016; Adnan, 2014). Beberapa penelitian seperti Melisa, (2018) mengatakan bahwa kadar C-organik kulit buah kopi adalah 45,3 \%, kadar nitrogen $2,98 \%$, fosfor $0,18 \%$ dan kalium $2,26 \%$ dan juga mengandung unsur $\mathrm{Ca}$, $\mathrm{Mg}, \mathrm{Mn}, \mathrm{Fe}, \mathrm{Cu}$ dan $\mathrm{Zn}$. Selain itu data lain bahwa kadar Corganik limbah kulit buah kopi adalah $10.80 \%$, kadar nitrogen 4,73\%, 
fosfor 0,21\% dan kalium 2,89\% (Direktorat Jenderal Perkebunan, 2014; Falahuddin, et al 2016), hal ini terbukti dalam penelitian Hutapea et al (2018) yang berhasil memberikan penambahan panjang batang tumbuhan karet yang paling tinggi yakni sekitar $50.98 \mathrm{~cm}$ dengan memberikan 15 ton/ha kompos kulit kopi. Sedangkan dalam penelitian Berlian et al (2015) menjelaskan bahwa penambahan kompos kulit kopi (Coffea robusta L.) dengan berat 90 gr pada media tanam dapat memberikan pertumbuhan dan perkembangan yang maksimum terhadap tanaman cabai keriting.

Penelitian terdahulu mengenai penggunaan pupuk kompos limbah kulit kopi telah berhasil mengungkap kandungan unsur haranya, selain itu telah dicoba pada beberapa tanaman sepert karet dan cabai keriting, sedangkan untuk kacang panjang masih sangat minim, sehingga dalam penelitian menggunakan Kacang panjang sebagai salah satu tanaman yang paling banyak di konsumsi di indonesia, dengan kulit kopi asli daerah Bima.

Tingginya konsumsi dan menurunya produksi Kacang panjang menjadi masalah tersendiri, Menurut Kementerian Pertanian (2013), peningkatan luas panen dari tahun 2012 hingga 2013 dari 75,739 ha menjadi 76,209 ha tidak diikuti dengan peningkatan produksi kacang panjang pada tahun tersebut yaitu menurun 455,562 ton menjadi 450,859 ton. Selain permasalahan penurunan produksi Kacang panjang juga juga maraknya penggunaan pupuk kimia sintetis secara terus menerus dalam usaha pertanian (Zulputra dan Hidayat, 2018). Kemudian banyaknya limbah kulit kopi yang tidak terpakai, memberikan dampak negatif akibat rasio $\mathrm{C} / \mathrm{N}$ bahan yang tinggi serta mengurangi pencemaran lingkungan sehingga peneliti tertarik mengambil penelitian ini dengan judul pengaruh kompos limbah kulit kopi (Coffea) terhadap pertumbuhan kacang panjang (Vigna sinensis L.). Penelitian ini bertujuan untuk mengetahui Pengaruh Kompos Limbah Kulit Kopi Terhadap Pertumbuhan Kacang Panjang.

\section{METODE}

\section{Tempat dan Waktu Penelitian}

Jenis penelitian ini adalah penelitian eksperimen dan pengamatan langsung di lapangan, dimana tekhnik pengumpulan data dilakukan ditempat penelitian. Penelitian ini dilaksanakan di kebun percobaan STKIP Bima pada bulan Meret 2018 sampai selesai.

\section{Alat dan bahan}

Peralatan yang dibutuhkan untuk pembuatan kompos yakni pisau, kotak, tutup kotak, alat penyiram, dan cangkul. Alat untuk pengambilan tanah yakni cangkul, sekop, dan karung. Untuk pengamatan pertumbuhan tanaman yaitu alat penyiram, timbangan, dan pisau. Bahan- bahan yang digunakan adalah tanah, timbangan dan Bibit kacang panjang, limbah kulit kopi, dedak, bakteri EM-4 dan cairan molase.

\section{Pembuatan Kompos}

Menurut Wijayanti (2014) tahap pembuatan kompos dimulai dari pengeringan kulit buah dan dicacah menjadi ukuran yang lebih kecil antara 0,5-1 cm untuk memudahkan proses dekomposisi (Berlian et al 2015) kemudian penyiapan bahan yang berupa EM4 (sebagai starter), molase (sebagai penambah makanan untuk organisme pendekomposisi). Molase dibuat dengan perbandingan 2:1 dengan EM4. 
Kulit kopi yang sudah digrinding dan dicampur dengan dedak dan molase secara merata serta EM4 sebanyak $1 \mathrm{ml}$ tiap $1 \mathrm{~kg}$ bahan. Selanjutnya tumpukan dibalik-balik setiap 3 hari sekali agar bahan tercampur dengan merata. Tanah yang diambil dari lahan dikeringanginkan, ditumbuk dan disaring hingga lolos ayakan $2 \mathrm{~mm}$. Tanah dicampur kompos kulit kopi sesuai perlakuan dan dimasukkan dalam polibag untuk pengamatan tanaman (Valentiah et al 2015)

\section{Rancangan Pecobaan}

Rancangan yang digunakan dalam penelitian ini adalah rancangan acak lengkap (RAL) dengan 1 perlakuan sebagai kontrol (A0) dan 4 macam perlakuan yaitu A1 (Kompos limbah kulit kopi 300 gram $1 \mathrm{~kg}$ tanah), A2 (Kompos limbah kulit kopi 400 gram :1 kg tanah), A3 (Kompos limbah kulit kopi 500 gram :1 kg tanah), dan A4 (Kompos limbah kulit kopi 600 gram :1 kg tanah). Masing-masing perlakuan dibuat 4 kali ulangan sehingga akan diperoleh 16 pot percobaan (Valentiah et al 2015). Sedangkan indikator pengamatan adalah pada tinggi tanaman dan jumlah daun (Azmin et al 2015) Pengamatan dilakukan setelah tanaman Vigna sinensis L. mencapai umur 2 minggu, 4 minggu, dan 6 minggu.

\section{Analisis Data}

Analisa data dalam penelitian ini yaitu menggunakan SPSS dengan melakukan uji Analysis of Variance (ANOVA). ANOVA merupakan metode pengujian untuk memeriksa hubungan antara dua atau lebih set data. Dengan kata lain ada hubungan antara set data dengan melakukan analisis varians (Fajrin et al 2016). Melalui analisa varian ini akan ditemukan hasil uji F-nya beda nyata atau tidak.

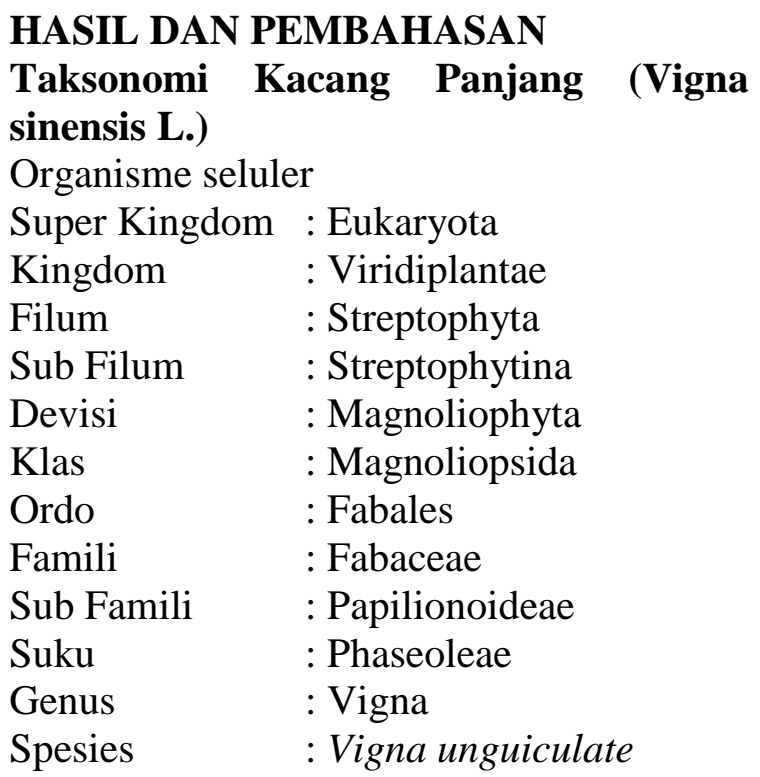

Nama Saintifik : Vigna unguiculata subsp. unguiculata (Grup Unguiculata ) (Grup Unguiculata )

Sinonim heterotip : Vigna sinensis L.

Referensi : NCBI Taxonomy ID: 3920

\begin{tabular}{|c|c|}
\hline T & \\
\hline Organisme selule & \\
\hline Super Kingdom & Eukaryota \\
\hline Kingdom & Viridiplantae \\
\hline Filum & Streptophyta \\
\hline Sub Filum & Streptophytina \\
\hline Devisi & : Magnoliophyt \\
\hline Klas & : Magnoliopsida \\
\hline Ordo & : Gentianales \\
\hline Famili & : Rubiaceae \\
\hline Sub Famili & : Ixoroideae \\
\hline uku & Coffeeae \\
\hline Jenus & : Coffea L. \\
\hline
\end{tabular}

Spesies : Coffea arabica L., Coffea benghalensis Heyne ex Schult., Coffea canephora Pierre ex Froehner, Coffea congensis, Coffea liberica W. Bull ex Hiern. dan Coffea stenophylla G. Don Nama Saintifik : Coffea L. Sinonim heterotip :Psilanthus

Referensi : NCBI Taxonomy ID: 13442 dan www.plants.usda.gov 
Pertumbuhan Vigna sinensis L. Setelah Diberi Pupuk Kompos Limbah Kulit Kopi

Menurut Azmin et al (2015) keberhasilan perumbuhanm tanaman dapat ditinjau dari berbagai aspek, salah satunya adalah pertumbuhan tinggi dan jumlah daun. Adapun hasil dalam penelitian ini dengan melalui 2 indikator pertumbuhan Vigna sinensis $L$. yaitu pada tinggi tanaman dan jumlah daun.

Secara keseluruhan setelah diamati pada hasil yang sama saat pengukuran pada umur 2 minggu, 4 minggu, dan 6 minggu, sehingga hasil pengamatan dapat rataratakan bahwa tinggi tanaman pada masingmasing perlakuan secara berturut-turut sama (tabel 1 dan gambar 1). Polta dan Subagiyono (2018) dalam (Purnomo et al, 2013) menjelaskan tersedianya unsur hara yang cukup serta terciptanya tekstur tanah yang gembur dapat merangsang pertumbuhan secara keseluruhan khususnya pertumbuhan batang sehingga memicu pada

Tabel 1. Rata-rata tinggi tanaman dan jumlah daun secara keseluruhan setelah penggunaan pupuk kompos kulit kopi setelah umur 2 Minggu, 4 Minggu dan 6 Minggu

\begin{tabular}{ccc}
\hline Perlakuan & $\begin{array}{c}\text { Rata-rata Tinggi } \\
\text { Tanaman secara keseluruhan }(\mathrm{cm}) \text { umur } \\
\text { 2M, 4M dan 6M }\end{array}$ & $\begin{array}{c}\text { Rata-rata Jumlah Daun } \\
\text { Tanaman secara keseluruhan umur } \\
\text { 2M, 4M dan 6M }\end{array}$ \\
\hline A0 & 32,2 & 3,67 \\
A1 & 33,00 & 19,00 \\
A2 & 48,90 & 24,67 \\
A3 & 61,27 & 3,38 \\
A4 & 61,27 & 3,38 \\
\hline
\end{tabular}

Keterangan: 2M (2 Minggu), 4M (4 Minggu), dan 6M (6 Minggu).

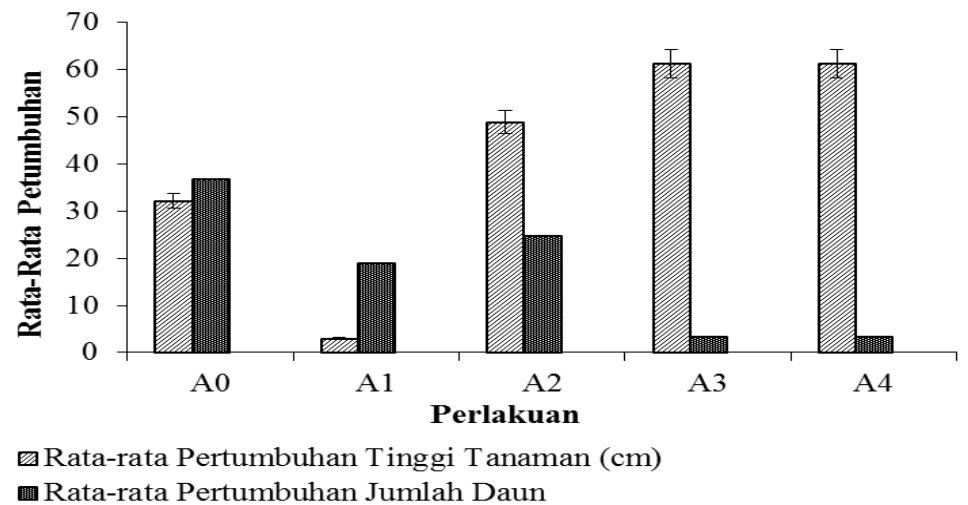

Gambar 1. Rata-rata pertumbuhan tinggi tanaman setelah penggunaan pupuk kompos kulit kopi Setelah umur 2 Minggu, 4 Minggu dan 6 Minggu

tinggi tanaman dari beberapa perlakuan (variasi dosis pupuk) menunjukan bahwa semakin tinggi dosis pupuk kompos limbah kulit kopi yang diberikan maka semakin meningkat pertumbuhan tinggi tanaman yaitu pada A4 (Kompos limbah kulit kopi $600 \mathrm{~g}$ ) dengan ukuran $61 \mathrm{~cm}$. Perlakuan atau dosis yang digunakan menunjukkan pertumbuhan tinggi tanaman (Polta dan Subagiyono 2018), selain itu Azmin et al (2015) juga menjelaskan bahwa salah satu peran penting unsur hara adalah membantu proses pembentukan energi dalam proses glikolisis dan proses fotosintesis yang digunakan untuk meningkatkan pertumbuhan tanaman, dimana unsur $\mathrm{P}$ 
diubah menjadi suatu ikatan pirofosfat dalam bentuk adenosine trifosfat (ATP) dan ADP. Menurut Salisbury dan

Ross dalam (Atmaja, 2017) ATP dan energi yang dihasilkan dari ATP tersebut berperan penting dalam penyerapan unsur hara lain seperti $\mathrm{P}, \mathrm{K}$ dan $\mathrm{Cu}$. Hal ini disebabkan karena penyerapan hara tersebut berlangsung melalui proses difusi, dimana pergerakan hara dari konsentrasi tinggi ke konsentrasi rendah membutuhkan energi ATP.

Sedangkan pada pertumbuhan jumlah daun mengalami peningkatan sampai pada dosis pupuk A2 (Kompos limbah kulit kopi 400 gram) sebanyak 25 helai akan tetapi pada dosis yang lebih tinggi yaitu A3 dan A4 mengalami penurunan pertumbuhan jumlah daun. Kemungkinan hal ini terjadi karena dosis pupuk yang terlalu tinggi, sehingga menyebabkan pertumbuhan daun menjadi menurun atau banyak yang rontok. Perlakuan atau dosis yang digunakan menunjukkan hasil yang sama saat pengukuran pada umur 2 minggu, 4 minggu, dan 6 minggu, sehingga hasil penyusun klorofil yang bertanggung jawab terhadap proses fotosintesa (Atmaja, 2017)

\section{Hasil Analisis nilai FHitung dan FTabel dari pertumbuhan tinggi Vigna sinensis} L.

Penggunaan limbah kulit kopi dengan dosis yang berbeda berpengaruh terhadap tinggi tanaman Vigna sinensis L., dibandingkan dengan pada media tanpa pemberian kompos kulit kopi (kontrol). Hal ini dibuktikan dengan hasil nalisis atau uji $\mathrm{F}$ terhadap tinggi tanaman Vigna sinensis $L$. pada umur 2 minggu setelah pemberian kompos kulit kopi menunjukkan nilai FHitung sebesar 8,13> FTabel $(4,07)$, sementara pada umur tanaman 4 minggu setelah pemberian kompos kulit kopi menunjukkan nilai Fhitung sebesar 7,99 > FTabel $(4,07)$ dan minggu ke 6 setelah pemberian kompos kulit kopi menunjukkan FHitung sebesar 14,34> FTabel $(4,07)$ (tabel 2). Hasil ini juga didukung oleh penelitian Berlian et al (2015) yang melaporkan bahwa limbah limbah kulit kopi mampu berpengaruh terhadap tnggi

Tabel 2. Hasil uji F beda nyata atau tidak Pemberian dosis pupuk kompos kulit kopi pada tinggi tanaman Vigna sinensis $L$.

\begin{tabular}{|c|c|c|}
\hline \multirow{2}{*}{$\begin{array}{c}\text { Umur } \\
\text { Tanaman }\end{array}$} & \multicolumn{2}{|c|}{$\begin{array}{c}\text { Nilai FHitung dan FTabel pertumbuhan tinggi tanaman } \\
\text { Vigna sinensis } L .\end{array}$} \\
\hline & FHitung & FTabel \\
\hline 2 Minggu & 8,13 & 4,07 \\
\hline 4 Minggu & 7,99 & 4,07 \\
\hline 6 Minggu & 14,34 & 4,07 \\
\hline
\end{tabular}

pengamatan dapat rata-ratakan bahwa jumlah daun pada masing-masing perlakuan secara berturut-turut sama (tabel 1 dan gambar 1). Pertumbuhan daun meningkat karena pupuk memiliki kecukupan hara $\mathrm{N}$, maka dapat ditandai dengan berjalannya proses pertumbuhan vegetatif yang lebih baik dan juga, nitrogen adalah integral tanaman Cabai Keriting.
Hasil Analisis nilai FHitung dan FTabel dari Banyakanya Daun Vigna sinensis L.
Penggunaan limbah kulit kopi dengan dosis yang berbeda memberikan pengaruh terhadap jumlah daun yang tumbuh. Hasil nalisis atau uji $\mathrm{F}$ menunjukan nilai FHitung sebesar 17,00 > FTabel $(4,07)$, sementara 
pada umur tanaman 4 minggu setelah pemberian kompos kulit kopi menunjukkan nilai Fhitung sebesar 7,58>FTabel $(4,07)$ dan minggu ke 6 setelah pemberian kompos kulit kopi menunjukkan FHitung sebesar $6,44>$ FTabel (4,07).

Tabel 3. Hasil uji F beda nyata atau tidak pada pemberian dosis pupuk kompos kulit kopi terhadap jumlah daun tanaman Vigna sinensis L..

\begin{tabular}{ccc}
\hline \multirow{2}{*}{ Umur } & \multicolumn{3}{c}{ Nilai FHitung dan FTabel jumlah daun } \\
Tanaman & FHitung & FTaba sinensis L. \\
\cline { 2 - 3 } & 17,00 & 4,07 \\
2 Minggu & 7,58 & 4,07 \\
4 Minggu & 6,44 & 4,07 \\
6 Minggu & &
\end{tabular}

\section{SIMPULAN}

Berdasarkan hasil penelitian dapat ditarik kesimpulan bahwa penggunaan pupuk kompos limbah kulit kopi mampu meningkatkan pertumbuhan tinggi dan jumlah daun dari tanaman kacang panjang Vigna sinensis L.. Seain itu hasil uji $\mathrm{F}$ memperlihatkan bahwa pertumbuhan tinggi dan jumlah daun dari tanaman kacang panjang (Vigna sinensis L.) memperlihatkan beda nyata antara Fhitung dan Ftabelnya.

\section{DAFTAR PUSTAKA}

Azmin, N. (2015). Pertumbuhan Carica (Carica pubescens) Dengan Perlakuan Dosis Pupuk Fospor Dan Kalium Untuk Mendukung Keberhasilan Transplantasi Di Lereng Gunung Lawu. EL-VIVO, 3 (1).

Atmaja I.S.W. (2017). Pengaruh Uji Minus One Test Pada Pertumbuhan Vegetatif Tanaman Mentimun. Jurnal Logika. 19(1) 63-68 ŁJURNAL ILMIAH

Afrizon (2016). Potensi Kulit Kopi Sebagai Bahan Baku Pupuk Kompos Di Propinsi Bengkulu. Balai Pengkajian Teknologi Pertanian Bengkulu. Jurnal ilmu dan teknologi pertanian. 2 (2) 21-31

Afrizon (2015). Potensi Kulit Kopi Sebagai Bahan Baku Pupuk Kompos Di

\section{SARAN}

Penelitian ini menunjukan hasil yang positif, sehingga untuk kedepanya perlu dilakukan penelitian lanjutan mengenai kandungan unsur hara tanah yang sudah dicampuri dengan pupuk kompos limbah kopi, kemudian di lakukan variasi dosis yang lebih banyak dan tidak hanya untuk tanaman hortikultura tetapi juga tanaman lain yang bernilai ekonomis tinggi.

Propinsi Bengkulu. Agritepa, 2(1) 2132

Adnan (2014). Pengaruh kompos kulit kopi dan interval aplikasi pupuk bio cair (Herbafarm) terhadap hasil jagung manis (Zea mays sacchrata) sturt. Jurnal Agriculture. 10 (2).

Berlian Z., Syarifah \& Sari D.S. (2015). Pengaruh Pemberian Limbah Kulit Kopi (Coffea robusta L.) Terhadap Pertumbuhan Cabai Keriting (Capsicum annum L.) Jurnal Biota 1(1) 22-32

Direktorat Jenderal Perkebunan (2014). Pedoman pemanfaatan limbah dari pembukaan lahan. Direktorat Jenderal Perkebunan. Departemen Pertanian.

Fajrin J., Pathurahman \& Pratama L.G. (2016). Aplikasi Metode Analysis Of 
Variance (Anova) Untuk Mengkaji Pengaruh Penambahan Silica Fume Terhadap Sifat Fisik Dan Mekanik Mortar. Jurnal Rekauasa Sipil. 12(1) $11-23$

Falahuddin I., Raharjeng A. R. P. \& Harmeni L. (2016). Pengaruh Pupuk Organik Limbah Kulit Kopi (Coffea Arabica L.) Terhadap Pertumbuhan Bibit Kopi. Jurnal Bioilmi 2 (2) 108120

Fahruddin (2012). Budidaya kacangkacangan, Yogyakarta. Kanisius.

Hutapea R., Armaini \& Isnaini (2018). Pemberian Beberapa Dosis Kompos Kulit Kopi Terhadap Pertumbuhan Bibit Karet (Hevea brasilliensis Muell Arg.) STUM Mini. JOM Faperta. 5(1) $1-13$

Haryanto (2011). Budidaya kacang panjang. Jakarta. Penebar Swadaya

Kementrian Pertanian (2013). Produksi Hortikultura. Diakses pada tanggal: 4 Desember 2014. 2010-2019. http://aplikasi.pertanian.go.id/ bdsp/hasil_kom.asp.

Melisa (2018). Studi Pemanfaatan Limbah Kulit Kopi Toraja Sebagai Bahan Pembuatan Kompos. Universitas Hasanuddin Makasar.

NCBI (2019). Classification of coffee. Taxonomy ID: 13442. Retrieved 07 mei 2019. https://www.ncbi.nlm.nih.gov/Taxono my/Browser/wwwtax.cgi?mode=Info \&id=13442\&lvl=3\&lin=f\&keep=1\&s rchmode $=1 \&$ unlock

NCBI (2019). Classification of Vigna unguiculata subsp. unguiculata. Taxonomy ID: 3920. Retrieved 05 mei

2019.

https://www.ncbi.nlm.nih.gov/Taxono my/Browser/wwwtax.cgi?mode=Info $\& \mathrm{id}=3920 \& \mathrm{lvl}=3 \& \mathrm{lin}=\mathrm{f} \& \mathrm{keep}=1 \& \mathrm{sr}$ chmode $=1 \&$ unlock

Polta A.K. \& Subagiono (2018). Pengaruh Pemberian Beberapa Jenis Pupuk Kandang Terhadap Pertumbuhan
Bibitkopi Varietas Robusta (Coffea robusta). Jurnal Sains Agro. 3(2) 1-9

Purnomo R., M. Santoso, \& Heddy S. (2013). Pengaruh Berbagai Macam Pupuk Organik Dan Anorganik Terhadap Pertumbuhan Dan Hasil Tanaman Mentimun. Jurnal Produksi Tanaman. 1(3) 93-100

Qasem J.R., \& Biftu K.N. (2010). Growth Analysis and Responses of Cowpea [Vigna Sinensis (L.) Savi Ex Hassk.] and Redroot Pigweed (Amaranthus retroflexus L.), Grown in Pure and Mixed Stands, to Density and Water Stresses. The Open Horticulture Journal. 3 21-30

Rizskywan P. (2014). Pengaruh Lama Pengomposan dan Dosis Kompos LimbahKulit Kopi Terhadap Pertumbuhan dan Hasil Tanaman Kacang Tanah (Arachis hypogea L.). Skripsi. Universitas Syiah Kuala Banda Aceh.

Simarmata E.R., Ardian \& Sa'diyah N. (2015). Penampilan karakter produksi kacang panjang (Vigna sinensis L.) Generasi f1 dan tetuanya. J. Agrotek Tropika. 3(3) $303-308$

Samadi (2013). Usaha tani kacang panjang. Yogyakarta. Kanisius.

USDA PLANTS Database (2019). Classification for Kingdom Plantae Down to Genus Coffea L. Retrieved $07 \quad$ mei 2019 https://plants.usda.gov/java/Classifica tionServlet? source $=$ display $\&$ classid $=$ COFFE

Valentiah F.V., Listyarini E., Prijono S. (2015). Aplikasi Kompos Kulit Kopi Untuk Perbaikan Sifat Kimia Dan Fisika Tanah Inceptisol Serta Meningkatkan Produksi Brokoli. Jurnal Tanah dan Sumberdaya Lahan. 2(1) 147-154.

Wijayanti, R. 2014. Pengaruh Pemberian Kompos Limbah Teh Terhadap 
Pertumbuhan Vegetatif Tanaman Jagung (Zea mays L.) dan Sumbangshnya pada Pokok Bahasan Pertumbuhan dan Perkembangan Tanaman di SMA/MA Kelas XII. Palembang : IAIN Raden Fatah Palembang.

Yudha H. K., Wirya G.N.A.S. \& Raka I G.N. (2016). Pembebasan Benih Kacang Panjang (Vigna sinensis L) dari Infeksi Bean Common Mosaic Virus (BCMV) melalui Perlakuan Dry Heat. E-Jurnal Agroekoteknologi Tropika. 5(2) 127-139

Zulputra \& Hidayat T. (2018). Respon Tanaman Kacang Panjang (Vigna sinensis L.) Terhadap Pemberian Pupuk Organik Cair Mikroorganisme Lokal Buah Mangga. Jurnal Sungkai 6 (1) 50-59 